\title{
Pengaruh Pemangkasan Akar dan Waktu Penyapihan Terhadap Pertumbuhan Bibit Tanaman Kemiri (Aleurites moluccana, Willd) Asal Stum
}

\author{
Maximus Louk ${ }^{a}$ dan Krisantus Tri Pambudi Raharjo ${ }^{\mathrm{b}}$ \\ ${ }^{a}$ Fakultas Pertanian, Universitas Timor, Kefamenanu, TTU - NTT, Indonesia. \\ ${ }^{b}$ Fakultas Pertanian, Universitas Timor, Kefamenanu, TTU - NTT, Indonesia.
}

\section{Article Info}

Article histor :

Received 22 Oktober 2016

Received in revised form 23 November 2016 Accepted 8 Januari 2017

\section{Keywords:}

Pemangkasan Akar

Waktu Penyapihan

Stum Kemiri

Aleurites maluccana, Willd

\begin{abstract}
Abstrak
Penggunaan anakan yang tumbuh liar sebagai bibit (stum) umum dilakukan pada tanaman kemiri oleh masyarakat di pulau Timor. Penelitian ini bertujuan untuk mengetahui Pengaruh Pemangkasan akar dan Waktu Penyapihan Terhadap Pertumbuhan Bibit Tanaman Kemiri (Aleurites maluccana, Willd.) Asal Stum dengan menggunakan Rancangan Acak Lengkap (RAL) faktorial $3 \times 3$ dengan 5 ulangan. Faktor pertama adalah pemangkasan akar yang terdiri dari 3 aras yaitu, Faktor pertama adalah pemangkasan akar yang terdiri dari 3 aras yaitu, $\mathrm{P}_{0}$ : Menyisakan panjang potongan $15 \mathrm{~cm}, \mathrm{P}_{1}$ : Menyisakan panjang potongan $10 \mathrm{~cm}$, dan $\mathrm{P}_{2}$ : Menyisakan panjang potongan $5 \mathrm{~cm}$. Faktor kedua adalah waktu Penyapihan, dengan 3 aras yakni, $C_{1}: 8$ minggu, $C_{2}$ : 9 minggu, dan $C_{3}: 10$ minggu. Pengamatn mengikuti : Tinggi Tanaman Jumlah Daun (Helai), Diameter Batang, Luas Daun, Bobot segar Akar, Bobot segar Batang. Bobot kering Akar, Bobot kering Batang. Hasil penelitian menunjukkan tidak terjadi interaksi antara panjang sisa potongan akar dengan waktu penyapihan pada semua parameter pengamatan. Pengaruh utama perlakuan sisa potongan akar $5 \mathrm{~cm}$ menghasilkan persentase peningkatan bobot kering tanaman terbaik $(298,7 \%)$. Pengaruh utama perlakuan waktu penyapihan tidak menunjukkan beda nyata pada semua parameter pengamatan. (02017 dipublikasikan oleh Savana Cendana.
\end{abstract}

\section{Pendahuluan}

Permasalahan dalam perbanyakan kemiri adalah benih kemiri memiliki kulit biji yang keras yang menyebabkan hambatan fisik dalam perkecambahannya Penyimpanan yang lama menurunkan daya tumbuhnya. Rosman dan Djauhariya (2006) menyatakan bahwa, perlakuan secara fisik maupun kimia terhadap benih kemiri, rata-rata perkecambahan meningkat lebih dari $85 \%$ untuk benih yang bagus. Bila diberi perlakuan, perkecambahan biasanya terjadi sekitar 15-20 hari setelah penanaman. Benih yang tidak diberi perlakuan umumnya baru berkecambah setelah 38-150 hari ditanam di persemaian. Selain itu juga dalam pengadaan bibit kemiri masa berbuah dan penanaman yang bersamaan. Cara mengatasi permasalahan ini adalah dengan menyimpan benih kemiri selama 4 5 bulan dan menyemaikannya pada bulan Juni sehingga pada bulan Desember dapat diperoleh bibit yang sesuai kriteria.

Masyarakat biasanya tidak melakukan penyimpanan benih kemiri untuk bahan perbanyakan tetapi menanam langsung buah kemiri yang jatuh atau menggunakan anakan yang tumbuh di bawah pohon sebagai bibit cabutan (stump). Namun penanamanan dengan kebiasaan ini tingkat keberhasilannya rendah sehingga tidak dapat memenuhi bila dalam jumlah yang besar.

Musim jatuhnya buah (masa panen) kemiri untuk wilayah P. Timor yaitu pada November-Desember bersamaan dengan musim penghujan, dan musim penanamannya. Biji yang jatuh biasanya langsung tumbuh dan menjadi anakan liar.

Anakan yang berasal dari biji yang tumbuh pada awal musim hujan (Desember) bila digunakan sebagai bibit pada penanaman bulan Januari-Februar belum cukup berkayu dan kurang bertahan untuk kelangsungan hidupnya terlebih bila kondisi curah hujan kurang. Pencabutan juga mudah merusak aka tanaman yang masih muda. Sejauh ini belum diketahui pengaruh terputusnya sebagian akar pada cara tanam yang demikian.

Mencabut anakan alami yang cukup berkayu di akhir musim kemarau (telah berumur $8-9$ bulan) dan menyiapkannya menjadi bibit sesuai kriteria dengan cara menyapih anakan dalam pembibitan selama beberapa waktu adalah upaya yang dapat ditempuh, sehingga daya tumbuhnya tinggi setelah ditanam di lapangan. Terputusnya akar saat mencabut, dan pemangkasan akar saat menyiapkan tanaman untuk pembibitan dapat mempengaruhi pertumbuhan bibit Belum ada laporan tentang pengaruh pemotongan akar terhadap anakan alami (stump) kemiri. Namun memotong akar secara alami akan merangsang pertumbuhan baru pada ujung potongan (Miller dan Neely, 1993). Permasalahannya adalah seberapa banyak bagian akar yang perlu dipotong dan selanjutnya seberapa lama stum tersebut membutuhkan waktu penyapihan yang menghasilkan daya tumbuh bibit paling optimal.

Morfologi sistem akar dapat dipengaruhi oleh pemupukan (Brissette 1991; Jacobs et al. 2004.), irigasi (Williams et al. 1988; Brissette 1991; Bayley dan Kietzka 1997), dan pemangkasan akar (Larson, 1975). Persentase kelangsungan hidup penyambungan (grafting) dengan batang bawah berumur 2 tahun pada tanaman kenari persia ( Juglans regia, L; walnut) meningkat sebesar $25 \%$ melalui pemangkasan akar (Yildiz et al., 2005). Penggunaan secara komersia dari pemangkasan akar meningkatkan dalam beberapa tahun terakhir dalam produksi apel di Amerika Serikat bagian timur (Ferree et al., 1992). Pada banyak spesies tanaman yang berbeda, pemangkasan akar terbukti mengurangi tingkat pertumbuhan tunas (Buttrose dan Mullins, 1968; Richards dan Rowe, 1977 Randolph dan Wiest, 1981; Schupp dan Ferree, 1990). Tingkat pertumbuhan aka tampaknya tetap tidak terpengaruh ataupun meningkat setelah pemangkasan akar. Namun laporan lain menunjukkan, peningkatan laju pertumbuhan aka terjadi dalam tanaman anggur (Buttrose dan Mullins, 1968), persik (Richards dan Rowe, 1977); dan Holly (Ilex paraguariensis, L.) (Randolph dan Wiest, 1981) setelah pemangkasan akar.

Regenerasi akar dalam menanggapi pemangkasan akar terjadi tepat di belakang potongan (Wilcox, H. 1955; Carlson, 1974). Namun, sebagian dar regenerasi akar dapat berasal dari minimal 4 inci $(10 \mathrm{~cm})$ di belakang potongan, tergantung pada spesies (Gilman dan Yeager, 1988). Pemangkasan akar, mengurangi pertumbuhan tunas, merangsang pertumbuhan akar baru sebagai upaya tanaman untuk mengembalikan rasio tajuk_akar seperti sebelum pemangkasan (Maggs, 1964; Richards dan Rowe, 1977; Randolph dan Wiest, 1981). Pemangkasan akar menginduksi penurunan rasio tajuk_akar (Tanaka, Walsted dan Borrecco, 1976; Bacon dan Bachelard, 1978; Randolph dan Wiest, 1981), dan berhubungan dengan peningkatan kinerja bibit pohon pascatransplanting (Benson dan Shepherd, 1977). Menurut Kramer dan Kozlowsk (1979), masing-masing spesies memiliki rasio tajuk akar yang khas. Ketika rasio berubah, seperti saat transplanting, tanaman merespon dengan mengalihkan asimilat untuk mengganti bagian yang dipangkas. Pemangkasan akar dapat meningkatkan produksi bulu akar dalam bola akar (Gilman, 1992).

Selanjutnya reaksi tanaman adalah untuk membangun kembali 'keseimbangan fungsional' dibuktikan dengan pemulihan rasio tajuk akar setelah pemangkasan akar (Richards dan Rowe, 1977; Randolph dan Wiest, 1981; Schupp dan Ferree, 1990). Ferree (1989) melaporkan bahwa pemangkasan aka pada bibit apel meningkatkan fraksi karbohidrat larut dan tidak larut dalam akar memberikan bukti lebih lanjut untuk redistribusi asimilasi dalam mendukung sistem akar. Redistribusi bobot kering ke akar setelah pemangkasan akar terjadi untuk mempromosikan penurunan pertumbuhan tunas. Namun, Geisler dan Ferree (1984) menyatakan bahwa peningkatan pertumbuhan akar, dirangsang oleh pemangkasan akar, hanya mengarah ke penurunan pertumbuhan tunas jika faktor-faktor pertumbuhan membatasi

Pada pemangkasan akar, waktu yang dibutuhkan untuk mengembalikan rasio tajuk akar tanaman: sangat bervariasi antar spesies. Dua puluh lima hari telah dilaporkan untuk bibit persik (Richards dan Rowe, 1977); lima puluh dua hari untuk apel (Schupp dan Ferree, 1990). Pengaruh faktor lingkungan dan fisiologis pada regenerasi akar; tingkat pemangkasan dan waktu pemangkasan akar juga berkontribusi terhadap variasi ini.

Setelah pemangkasan akar ada regenerasi yang cepat dari pertumbuhan akar, yang diperkirakan akan disertai dengan pemulihan serapan air. Richards dan Rowe (1977) mengamati bahwa serapan air pulih 10 hari setelah pemangkasan akar pada tanaman persik, dan ini terkait erat pemulihan sistem akar. Transpiras dan laju fotosintesis juga menunjukan pulih setelah regenerasi sistem akar, tetapi pada tingkat yang lebih lambat dari potensi air (Geisler dan Ferree, 1984).

Serapan hara mungkin menurun hanya karena daerah penyerapan berkurang saat setelah pemangkasan akar. Setelah sistem akar beregenerasi, serapan dapa meningkat sesuai peningkatan pertumbuhan akar (Geisler dan Ferree, 1984) Kemudian pasokan nutrisi untuk tajuk terjadi sebagai respons pemangkasan akar (McDavid et al., 1973). Sebaliknya, Schupp dan Ferree (1992) pemotongan penurunan penyerapan nutrisi sebagai penyebab berkurangnya pertumbuhan setelah pemangkasan akar. Pohon yang akarnya dipangkas selanjutnya dua kali melalui musim, secara nyata memiliki kandungan yang lebih tinggi dari nitrogen, fosfor, kalsium, magnesium, besi dan boron dalam daun dibandingkan dengan tanaman yang tidak dipangkas akarnya. Richards dan Rowe (1977) mengamati tidak terjadi kekurangan nutrisi pada bibit peach setelah pemangkasan akar.

Febriani (2010) melaporkan "pengaruh pemotongan akar dan lama aerasi media terhadap pertumbuhan selada (Lactuca sativa L.) nutrient film technique", hasilnya menunjukkan bahwa pemotongan akar mampu memperluas perakaran tanaman dan meningkatkan berat segar akar. Laporan lain (Ma, et al., 2013) menunjukkan bahwa pemangkasan akar secara signifikan mengubah sensitivitas nHRS dan peningkatan water use efficiency (WUE) dari gandum musim dingin di tanah kekeringan maupun disiram menengah, tetapi menurunkan tolerans kekeringan dari gandum musim dingin di tanah kekeringan parah

Stump adalah bibit yang berasal dari semai maupun anakan alami yang telah dihilangkan seluruh daun dan bulu-bulu akarnya sehingga yang tersisa hanya sebagian batang dan sebagian akar utama. Stump dapat digunakan untuk memindahkan bibit atau anakan alami yang sudah cukup besar dengan diameter 
batang 2-3 $\mathrm{cm}$. Stump juga dapat digunakan untuk mempermudah pengiriman bibit, karena lebih ringan dan ringkas ketika dikirimkan (Pramono et al., 2010).

Untuk mendapatkan bibit kemiri dapat ditempuh dengan cara, generatif (biji), vegetatif (cangkok) dan sambungan (graftting). Pada penyambungan diperlukan batang bawah (understump) dan batang atas (entrys). Dijelaskan pula bahwa, setelah perkecambahan dilanjutkan dengan menanam kecambah yang tumbuh $(5-10 \mathrm{~cm})$ ke bedeng sapih atau polybag (penyapihan persemaian ke2) dan untuk melindungi dari sengatan matahari perlu diberi naungan $50 \%$ hingga bulan ke-3, 30\% penaungan hingga bulan ke $7-10$, dan selanjutnya tidak diberi naungan lagi (masa aklimatisasi) sampai dipindahtanam (transplanting) Naungan juga diperlukan untuk pemeliharaan bibit asal sambungan (Dirjen Perkebunan, Kementan, 2006).

Di Propinsi NTT, penanaman secara langsung anakan alami yang dicabut sebagai stump ke areal kebun merupakan alternatif yang ditempuh oleh masyarakat dalam perbanyakan kemiri. Dari tinjauan di atas maka, untuk memperoleh bibit asal cabutan anakan alami yang berkualitas maka sebaiknya perlu dipelihara (penyapihan) selama beberapa waktu di musim kemarau dan selanjutnya ditanam di musim hujan. Lamanya waktu penyapihan bibit asal cabutan (stump) melalui pemeliharaan dalam pembibitan menggunakan naungan merupakan cara untuk memberikan lingkungan yang baik bagi tanaman, sehingga dapat tersedia bibit kemiri yang baik pula sebelum dipindahtanam (transplanting).

Di Indonesia umur bibit kemiri (asal pengecambahan biji) sampai dengan siap tanam tidak sama antara satu daerah dengan daerah lainnya, tergantung kondisi bibit dan lingkungannya, umumnya pada umur antara 4-6 bulan, ada pula yang menanam pada umur $7-10$ bulan dan ada pula yang menanam pada umur 3 bulan. Waktu bertanampun berbeda tergantung musim hujan. Di Lombok pada bulan November, sedangkan di Bima pada bulan Desember (Hamid, 1991). Belum ada laporan terdahulu berapa lama waktu yang diperlukan untuk penyapihan bibit asal cabutan anakan alami (stump) pada kondisi pembibitan di bawah naungan.

\section{Metode}

Penelitian ini dilaksanakan pada bulan Januari sampai Maret 2016, di Desa Dirma Kecamatan Malaka Timur, Kabupaten Malaka, Nusa Tenggara Timur. Rancangan yang digunakan dalam penelitian ini adalah Rancangan Acak Lengkap (RAL) pola faktorial. Faktor pertama adalah pemangkasan akar yang terdiri dari 3 aras yaitu, $\mathrm{P}_{0}$ : Menyisakan panjang potongan $15 \mathrm{~cm}, \mathrm{P}_{1}$ : Menyisakan panjang potongan $10 \mathrm{~cm}$, dan $\mathrm{P}_{2}$ : Menyisakan panjang potongan $5 \mathrm{~cm}$. Faktor kedua adalah waktu penyapihan, dengan 3 aras yakni, $\mathrm{C}_{1}: 8$ minggu, $\mathrm{C}_{2}: 9$ minggu, dan $\mathrm{C}_{3:} 10$ minggu.

Data hasil pengamatan kemudian dianalisis dengan menggunakan sidik ragam (Anova) Rancangan Acak Lengkap (RAL). Rata-rata perlakuan selanjutnya diuji lanjut dengan menggunakan Duncan Multiple Range Test (DMRT) dengan tingkat signifikasi 5\% sesuai petunjuk Adji (2000). Analisis data menggunakan program SAS 9.1.

\section{Hasil dan Pembahasan}

\subsection{Tinggi Tanaman Awal}

Hasil sidik ragam (Anova) pengamatan awal sebelum diterapkan perlakuan menunjukkan tidak adanya beda nyata tinggi tanaman (Tabel 1.).

Tabel 1. Tinggi Tanaman Awal (cm)

\begin{tabular}{ccccc}
\hline Sisa & \multicolumn{3}{c}{ Waktu penyapihan (minggu) } & \multirow{2}{*}{ Rerata } \\
\cline { 2 - 4 } Potongan Akar & 13 & 14 & 15 & \\
\hline 15 & 64,33 & 55,33 & 65,67 & 61,78 a \\
10 & 61,00 & 64,00 & 43,93 & $56,31 \mathrm{a}$ \\
5 & 60,33 & 70,33 & 48,08 & 59,58 a \\
\hline Rerata & 61,89 a & 63,22 a & 52,56 a & $(-)$ \\
\hline Keterangan: Angka pada baris dan kolom diikuti huruf sama tidak berbeda pada taraf nyata
\end{tabular}

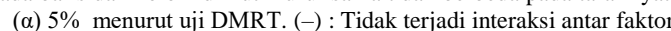

\subsection{Berat Segar Tanaman Awal}

Demikian pula pada pengamatan bobot segar tanaman sebelum diterapkan perlakuan, hasil sidik ragam (Anova) menunjukkan tidak adanya beda nyata (Tabel 2.)

\section{Tabel 2. Berat Segar Tanaman Awal (g)}

\begin{tabular}{ccccc}
\hline Sisa & \multicolumn{3}{c}{ Waktu penyapihan (minggu) } & \multirow{2}{*}{ Rerata } \\
\cline { 2 - 4 } Potongan Akar & 13 & 14 & 15 & \\
\hline 15 & 35,70 & 23,63 & 35,83 & $31,72 \mathrm{a}$ \\
10 & 38,97 & 35,90 & 27,20 & $34,02 \mathrm{a}$ \\
5 & 29,60 & 32,03 & 31,83 & $31,16 \mathrm{a}$ \\
\hline Rerata & 34,76 a & 30,52 a & 31,62 a & $(-)$ \\
\hline \multicolumn{2}{l}{ Keterangan: Angka pada baris dan kolom diikuti huruf sama tidak berbeda pada taraf nyata }
\end{tabular}

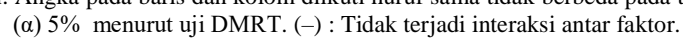

\subsection{Bobot kering Tanaman Awal}

Hasil sidik ragam (Anova) pengamatan awal sebelum diterapkan perlakuan menunjukkan tidak adanya beda nyata bobot kering tanaman awal (Tabel 3.).
Tabel 3. Bobot Kering Tanaman Awal (g)

\begin{tabular}{ccccc}
\hline Sisa Potongan & \multicolumn{3}{c}{ Waktu penyapihan (minggu) } & \multirow{2}{*}{ Rerata } \\
\cline { 2 - 4 } Akar & 13 & 14 & 15 & \\
\hline 15 & 5,36 & 3,55 & 5,38 & $4,76 \mathrm{a}$ \\
10 & 5,85 & 5,39 & 4,08 & $5,10 \mathrm{a}$ \\
5 & 4,44 & 4,81 & 4,78 & $4,67 \mathrm{a}$ \\
\hline Rerata & $5,21 \mathrm{a}$ & $4,58 \mathrm{a}$ & $4,74 \mathrm{a}$ & $(-)$ \\
\hline Keterangan: Angka pada baris dan kolom diikuti huruf sama tidak berbeda pada taraf nyata
\end{tabular}

Keterangan: Angka pada baris dan kolom diikuti huruf sama tidak berbeda pada taraf nyata (a) 5\% menurut uji DMRT. (-) : Tidak terjadi interaksi antar faktor.

\subsection{Tinggi Tanaman Setelah Panen}

Hasil sidik ragam (Anova) menunjukkan tidak terjadi pengaruh interaksi antara pemangkasan akar dan waktu penyapihan pada tinggi tanaman setelah panen. Pengaruh utama sisa potongan akar $5 \mathrm{~cm}$ menghasilkan tanaman paling tinggi $(84,56 \mathrm{~cm})$ walaupun tidak berbeda nyata dibanding tanaman dengan sisa potongan akar $10 \mathrm{~cm}$ dan $15 \mathrm{~cm}$. Waktu penyapihan 14 minggu menghasilkan tanaman paling tinggi $(77,0 \mathrm{~cm})$ walaupun tidak berbeda nyata dibanding tanaman dengan waktu penyapihan 15 minggu, tetapi berbeda nyata dibanding tanaman dengan waktu penyapihan 13 minggu (Tabel 4.).

Tabel 4. Tinggi Tanaman Setelah Panen (cm)

\begin{tabular}{ccccc}
\hline Sisa & \multicolumn{3}{c}{ Waktu penyapihan (minggu) } & \multirow{2}{*}{ Rerata } \\
\cline { 2 - 4 } Potongan Akar & 13 & 14 & 15 & \\
\hline 15 & 74,33 & 61,67 & 76,33 & $70,78 \mathrm{~b}$ \\
10 & 75,77 & 76,67 & 72,33 & $74,92 \mathrm{ab}$ \\
5 & 79,00 & 92,67 & 82,00 & $84,56 \mathrm{a}$ \\
\hline Rerata & $76,37 \mathrm{a}$ & $77,00 \mathrm{a}$ & $76,89 \mathrm{a}$ & $(-)$ \\
\hline
\end{tabular}

Keterangan: Angka pada baris dan kolom diikuti huruf sama tidak berbeda pada taraf nyata ( $\alpha$ ) $5 \%$ menurut uji DMRT. (-) : Tidak terjadi interaksi antar faktor.

\subsection{Berat Segar tanaman Setelah Panen}

Hasil sidik ragam (Anova) menunjukkan tidak terjadi pengaruh interaksi antara pemangkasan akar dan waktu penyapihan pada berat segar tanaman setelah panen. Pengaruh utama sisa potongan akar $5 \mathrm{~cm}$ menghasilkan tanaman paling tinggi $(84,56 \mathrm{~g})$ berbeda nyata dibanding tanaman dengan sisa potongan akar $10 \mathrm{~cm}$ dan $15 \mathrm{~cm}$. Waktu penyapihan 13 minggu menghasilkan tanaman paling tinggi $(68,38 \mathrm{~g})$ dibandingkan perlakuan lainnya (Tabel 5.).

Tabel 5. Berat Segar Tanaman Setelah Panen (g)

\begin{tabular}{ccccc}
\hline Sisa Potongan & \multicolumn{3}{c}{ Waktu penyapihan (MST) } & \multirow{2}{*}{ Rerata } \\
\cline { 2 - 4 } Akar & 13 & 14 & 15 & \\
\hline 15 & 61,17 & 34,40 & 54,23 & $49,93 \mathrm{~b}$ \\
10 & 65,07 & 62,57 & 50,50 & $59,38 \mathrm{~b}$ \\
5 & 78,90 & 95,13 & 86,03 & $86,69 \mathrm{a}$ \\
\hline Rerata & $68,38 \mathrm{a}$ & $64,03 \mathrm{a}$ & $63,59 \mathrm{a}$ & $(-)$ \\
\hline
\end{tabular}

Keterangan: Angka pada baris dan kolom diikuti huruf sama tidak berbeda pada taraf nyata (a) $5 \%$ menurut uji DMRT. (-) : Tidak terjadi interaksi antar faktor.

\subsection{Bobot Segar Akar Setelah Panen}

Hasil sidik ragam (Anova) menunjukkan tidak terjadi pengaruh interaksi antara pemangkasan akar dan waktu penyapihan pada bobot segar akar setelah panen. Pengaruh utama sisa potongan akar $5 \mathrm{~cm}$ menghasilkan bobot segar akar tanaman paling berat $(13,61 \mathrm{~g})$ walaupun berbeda nyata dibanding tanaman dengan sisa potongan akar $10 \mathrm{~cm}$ dan $15 \mathrm{~cm}$. Waktu penyapihan 13 minggu menghasilkan bobot segar akar tanaman paling berat $(10,94 \mathrm{~g})$ dibandingkan perlakuan lainnya (Tabel 6.).

\section{Tabel 6. Bobot Segar Akar (g)}

\begin{tabular}{ccccc}
\hline Sisa & \multicolumn{2}{c}{ Waktu penyapihan (minggu) } & \multirow{2}{*}{ Rerata } \\
\cline { 2 - 4 } Potongan Akar & 13 & 14 & 15 & \\
\hline 15 & 7,87 & 3,03 & 4,73 & $5,21 \mathrm{~b}$ \\
10 & 10,87 & 8,57 & 5,40 & $8,28 \mathrm{~b}$ \\
5 & 14,10 & 11,33 & 15,40 & $13,61 \mathrm{a}$ \\
\hline Rerata & $10,94 \mathrm{a}$ & $7,64 \mathrm{a}$ & $8,51 \mathrm{a}$ & $(-)$ \\
\hline
\end{tabular}

Keterangan: Angka pada baris dan kolom diikuti huruf sama tidak berbeda pada taraf nyata $(\alpha) 5 \%$ menurut uji DMRT. (-) : Tidak terjadi interaksi antar faktor.

\subsection{Panjang Akar}

Hasil sidik ragam (Anova) menunjukkan tidak terjadi pengaruh interaksi antara pemangkasan akar dan waktu penyapihan pada panjang akar setelah panen.

Tabel 7. Panjang Akar $(\mathrm{cm})$

\begin{tabular}{ccccc}
\hline Sisa Potongan & \multicolumn{3}{c}{ Waktu penyapihan (minggu) } & \multirow{2}{*}{ Rerata } \\
\cline { 2 - 4 } Akar & 13 & 14 & 15 & \\
\hline 15 & 542,33 & 240,33 & 374,33 & $385,67 \mathrm{a}$ \\
10 & 652,67 & 637,00 & 394,00 & $561,22 \mathrm{a}$ \\
5 & 635,67 & 432,67 & 626,00 & $564,78 \mathrm{a}$ \\
\hline Rerata & $610,22 \mathrm{a}$ & $436,67 \mathrm{a}$ & $464,78 \mathrm{a}$ & $(-)$ \\
\hline
\end{tabular}

Keterangan: Angka pada baris dan kolom diikuti huruf sama tidak berbeda pada taraf nyata (a) $5 \%$ menurut uji DMRT. (-) : Tidak terjadi interaksi antar faktor. 
Pengaruh utama sisa potongan akar $5 \mathrm{~cm}$ menghasilkan tanaman dengan akar paling panjang $(564,78 \mathrm{~cm})$ walaupun tidak berbeda nyata dibanding tanaman dengan sisa potongan akar $10 \mathrm{~cm}$ dan $15 \mathrm{~cm}$. Waktu penyapihan 13 minggu menghasilkan tanaman dengan akar paling panjang $(610,22 \mathrm{~cm})$ walaupun tidak berbeda nyata dibanding tanaman dengan waktu penyapihan 15 minggu dan 13 minggu (Tabel 7.).

\subsection{Bobot Kering Tanaman}

Hasil sidik ragam (Anova) menunjukkan tidak terjadi pengaruh interaksi antara pemangkasan akar dan waktu penyapihan pada bobot kering tanaman setelah panen. Pengaruh utama sisa potongan akar $5 \mathrm{~cm}$ menghasilkan tanaman dengan bobot kering paling berat $(18,01 \mathrm{~g})$ berbeda nyata dibanding tanaman dengan sisa potongan akar $10 \mathrm{~cm}$ dan $15 \mathrm{~cm}$. Waktu penyapihan 13 minggu menghasilkan tanaman dengan bobot kering paling berat $(13,86 \mathrm{~g})$ walaupun tidak berbeda nyata dibanding tanaman dengan waktu penyapihan 15 minggu dan 13 minggu (Tabel 8.).

Tabel 8. Bobot Kering Tanaman (g)

\begin{tabular}{ccccc}
\hline Sisa Potongan & \multicolumn{2}{c}{ Waktu penyapihan (minggu) } & \multirow{2}{*}{ Rerata } \\
\cline { 2 - 4 } Akar & 13 & 14 & 15 & \\
\hline 15 & 12,10 & 7,00 & 10,85 & $9,98 \mathrm{~b}$ \\
10 & 14,21 & 13,72 & 10,49 & $12,81 \mathrm{~b}$ \\
5 & 15,26 & 20,68 & 18,10 & $18,01 \mathrm{a}$ \\
\hline Rerata & $13,86 \mathrm{a}$ & $13,80 \mathrm{a}$ & $13,15 \mathrm{a}$ & $(-)$ \\
\hline Keterangan: Angka pada baris dan kolom diikuti huruf sama tidak berbeda pada taraf nyata
\end{tabular}
(a) $5 \%$ menurut uji DMRT. (-) : Tidak terjadi interaksi antar faktor.

\subsection{Bobot Kering Akar}

Hasil sidik ragam (Anova) menunjukkan tidak terjadi pengaruh interaksi antara pemangkasan akar dan waktu penyapihan pada bobot kering akar setelah panen. Pengaruh utama sisa potongan akar $5 \mathrm{~cm}$ menghasilkan bobot kering akar paling berat $(1,699 \mathrm{~g})$ berbeda nyata dibanding tanaman dengan sisa potongan akar $10 \mathrm{~cm}$ dan $15 \mathrm{~cm}$. Waktu penyapihan 13 minggu menghasilkan bobot kering akar tanaman paling berat $(1,297 \mathrm{~g})$ walaupun tidak berbeda nyata dibanding tanaman dengan waktu penyapihan 15 minggu 14 minggu (Tabel 9.).

Tabel 9. Bobot Kering Akar (g)

\begin{tabular}{ccccc}
\hline Sabel 9. Bobot Kering Akar $(\mathrm{g})$ & \multirow{2}{*}{ Rerata } \\
\cline { 2 - 4 } Potongan Akar & 13 & \multicolumn{2}{c}{ Waktu penyapihan (minggu) } & \\
\hline 15 & 1,063 & 0,383 & 0,523 & $0,657 \mathrm{~b}$ \\
10 & 1,390 & 1,117 & 0,723 & $1,077 \mathrm{~b}$ \\
5 & 1,437 & 1,697 & 1,963 & $1,699 \mathrm{a}$ \\
\hline Rerata & $1,297 \mathrm{a}$ & $1,066 \mathrm{a}$ & $1,070 \mathrm{a}$ & $(-)$
\end{tabular}

Keterangan: Angka pada baris dan kolom diikuti huruf sama tidak berbeda pada taraf nyata (a) $5 \%$ menurut uji DMRT. (-) : Tidak terjadi interaksi antar faktor.

\subsection{Luas Daun}

Hasil sidik ragam (Anova) menunjukkan tidak terjadi pengaruh interaksi antara pemangkasan akar dan waktu penyapihan pada luas daun setelah panen. Pengaruh utama sisa potongan akar $5 \mathrm{~cm}$ menghasilkan tanaman dengan daun paling luas $\left(1507,98 \mathrm{~cm}^{2}\right)$ berbeda nyata dibanding tanaman dengan sisa potongan akar $10 \mathrm{~cm}$ dan $15 \mathrm{~cm}$. Waktu penyapihan 13 minggu menghasilkan tanaman dengan daun paling luas $\left(1120,59 \mathrm{~cm}^{2}\right)$ walaupun tidak berbeda nyata dibanding tanaman dengan waktu penyapihan 14 minggu dan 15 minggu (Tabel 10.)

Tabel 10. Luas Daun $\left(\mathrm{cm}^{2}\right)$

\begin{tabular}{ccccc} 
Tabel 10. Luas Daun $\left(\mathrm{cm}^{2}\right)$ & \multicolumn{3}{c}{ Waktu penyapihan (minggu) } & \multirow{2}{*}{ Rerata } \\
\cline { 2 - 4 } Sisa Potongan & 13 & 14 & 15 & \\
Akar & 793,46 & 424,58 & 657,29 & $625,11 \mathrm{c}$ \\
15 & 1133,19 & 902,30 & 783,44 & $939,64 \mathrm{~b}$ \\
10 & 1435,12 & 1612,72 & 1476,10 & $1507,98 \mathrm{a}$ \\
\hline 5 & $1120,59 \mathrm{a}$ & $979,87 \mathrm{a}$ & $972,28 \mathrm{a}$ & $(-)$ \\
\hline Rerata & &
\end{tabular}

Keterangan: Angka pada baris dan kolom diikuti huruf sama tidak berbeda pada taraf nyata (a) $5 \%$ menurut uji DMRT. (-) : Tidak terjadi interaksi antar faktor.

\subsection{Persentase Peningkatan Tinggi Tanaman (\%)}

Hasil sidik ragam (Anova) menunjukkan tidak terjadi pengaruh interaksi antara pemangkasan akar dan waktu penyapihan pada persentase peningkatan tinggi tanaman setelah panen.

Tabel 11. Persentase Peningkatan Tinggi Tanaman (\%)

\begin{tabular}{ccccc}
\hline Sisa & \multicolumn{2}{c}{ Waktu penyapihan (minggu) } & \multirow{2}{*}{ Rerata } \\
\cline { 2 - 4 } Potongan Akar & 13 & 14 & 15 & \\
\hline 15 & 15,08 & 11,91 & 16,67 & $14,55 \mathrm{~b}$ \\
10 & 22,10 & 20,69 & 19,18 & $20,66 \mathrm{~b}$ \\
5 & 33,08 & 32,09 & 28,45 & $31,21 \mathrm{a}$ \\
\hline Rerata & $23,42 \mathrm{a}$ & $21,56 \mathrm{a}$ & $21,44 \mathrm{a}$ & $(-)$
\end{tabular}

Keterangan: Angka pada baris dan kolom diikuti huruf sama tidak berbeda pada taraf nyata (a) $5 \%$ menurut uji DMRT. (-) : Tidak terjadi interaksi antar faktor.

Pengaruh utama sisa potongan akar $5 \mathrm{~cm}$ menghasilkan persentase peningkatan tinggi tanaman lebih tinggi $(31,21 \%)$ berbeda nyata dibanding tanaman dengan sisa potongan akar $10 \mathrm{~cm}$ dan $15 \mathrm{~cm}$. Waktu penyapihan 13 minggu menghasilkan persentase peningkatan tinggi tanaman lebih tinggi $(23,42$ $\%$ ) walaupun tidak berbeda nyata dibanding tanaman dengan waktu penyapihan 14 minggu, dan 15 minggu (Tabel 11.).

\subsection{Persentase Peningkatan Bobot Kering Tanaman}

Hasil sidik ragam (Anova) menunjukkan tidak terjadi pengaruh interaksi antara pemangkasan akar dan waktu penyapihan persentase peningkatan bobot kering batang daun setelah panen. Pengaruh utama sisa potongan akar $5 \mathrm{~cm}$ menghasilkan persentase peningkatan bobot kering batang daun lebih tingg $(298,86 \%)$ berbeda nyata dibanding tanaman dengan sisa potongan akar $10 \mathrm{~cm}$ dan $15 \mathrm{~cm}$. Waktu penyapihan 14 minggu menghasilkan persentase peningkatan bobot kering tanaman lebih tinggi $(192,82 \%)$ walaupun tidak berbeda nyata dibanding tanaman dengan waktu penyapihan 15 minggu dan 13 minggu (Tabel 12.).

Tabel 12. Persentase Peningkatan Bobot Kering Tanaman (\%)

\begin{tabular}{ccccc}
\hline Sisa & \multicolumn{3}{c}{ Waktu penyapihan (minggu) } & \multirow{2}{*}{ Rerata } \\
\cline { 2 - 4 } Potongan Akar & 13 & 14 & 15 & \\
\hline 15 & 122,05 & 92,30 & 104,46 & $106,27 \mathrm{~b}$ \\
10 & 140,53 & 149,95 & 147,65 & $146,04 \mathrm{~b}$ \\
5 & 258,29 & 336,20 & 302,09 & $298,86 \mathrm{a}$ \\
\hline Rerata & $173,62 \mathrm{a}$ & $192,82 \mathrm{a}$ & $184,73 \mathrm{a}$ & $(-)$ \\
\hline
\end{tabular}

Keterangan: Angka pada baris dan kolom diikuti huruf sama tidak berbeda pada taraf nyata (a) $5 \%$ menurut uji DMRT. (-) : Tidak terjadi interaksi antar faktor.

\subsection{Nisbah Bobot Kering Tanaman}

Hasil sidik ragam (Anova) menunjukkan tidak terjadi pengaruh interaksi antara pemangkasan akar dan waktu penyapihan pada nisbah bobot kering tanaman setelah panen. Pengaruh utama sisa potongan akar $5 \mathrm{~cm}$ menghasilkan nilai nisbah bobot kering tanaman paling rendah $(11,04)$ walaupun tidak berbeda nyata dibanding tanaman dengan sisa potongan akar $10 \mathrm{~cm}$ dan $15 \mathrm{~cm}$. Waktu penyapihan 13 minggu menghasilkan nilai nisbah bobot kering tanaman setelah panen. Pengaruh utama sisa potongan akar $15 \mathrm{~cm}$ menghasilkan nisbah bobot kering tanaman paling besar $(23,01 \mathrm{~g})$ walaupun tidak berbeda nyata dibanding tanaman dengan waktu penyapihan 15 minggu, dan 13 minggu (Tabel 13.).

Tabel 13. Nisbah Bobot Kering Tajuk Akar

\begin{tabular}{ccccc}
\hline Sisa & \multicolumn{3}{c}{ Waktu penyapihan (minggu) } & \multirow{2}{*}{ Rerata } \\
\cline { 2 - 4 } Potongan Akar & 13 & 14 & 15 & \\
\hline 15 & 13,83 & 43,89 & 21,01 & $26,24 \mathrm{a}$ \\
10 & 11,51 & 12,76 & 14,26 & $12,85 \mathrm{a}$ \\
5 & 10,65 & 12,37 & 10,10 & $11,04 \mathrm{a}$ \\
\hline Rerata & $12,00 \mathrm{a}$ & $23,01 \mathrm{a}$ & $15,12 \mathrm{a}$ & $(-$ ) \\
\hline Keterangan: Angka pada baris dan kolom diikuti huruf sama tidak berbeda pada taraf nyata
\end{tabular}

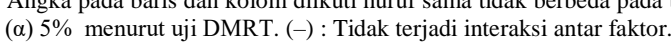

\subsection{Indeks Luas Daun}

Hasil sidik ragam (Anova) menunjukkan tidak terjadi interaksi antara panjang potongan akar dan waktu penyapihan pada indeks luas daun. Pengaruh utama sisa potongan akar $5 \mathrm{~cm}$ menghasilkan bobot indeks luas daun paling baik $(8,53)$ walaupun tidak berbeda nyata dibanding tanaman dengan sisa potongan akar $10 \mathrm{~cm}$ dan $15 \mathrm{~cm}$. Waktu penyapihan 13 minggu menghasilkan bobot indeks luas daun tanaman setelah panen. Pengaruh utama sisa potongan akar $15 \mathrm{~cm}$ menghasilkan bobot indeks luas daun tanaman paling baik $(6,34)$ walaupun tidak berbeda nyata dibanding tanaman dengan waktu penyapihan 14 minggu, tetapi berbeda nyata dibanding tanaman dengan waktu penyapihan 15 minggu

Nilai ILD >dengan sisa potongan $5 \mathrm{~cm}$ menggambarkan adanya saling menaungi di antara daun yang mengakibatkan daun yang ternaungi pada lapisan bawah tajuk mendapat cahaya yang kurang dan karenanya dapat mempunyai laju fotosintesis yang lebih rendah dari daun yang tidak ternaungi. Tetapi perlu diingat bahwa ILD $\leq$ sisa potongan $5 \mathrm{~cm}$ tidak berarti tanpa naungan. Ini sangat tergantung pada morfologi daun (bentuk dan posisi daun) (Tabel 14.)

Tabel 14. Indeks Luas Daun (ILD)

\begin{tabular}{ccccc}
\hline Sisa & \multicolumn{3}{c}{ Waktu penyapihan (minggu) } & \multirow{2}{*}{ Rerata } \\
\cline { 2 - 4 } Potongan Akar & 13 & 14 & 15 & \\
\hline 15 & 4,49 & 2,40 & 3,72 & $3,54 \mathrm{c}$ \\
10 & 6,41 & 5,10 & 4,43 & $5,32 \mathrm{~b}$ \\
5 & 8,12 & 9,12 & 8,35 & $8,53 \mathrm{a}$ \\
\hline Rerata & $6,34 \mathrm{a}$ & $5,54 \mathrm{a}$ & $5,50 \mathrm{a}$ & $(-)$ \\
\hline
\end{tabular}

Keterangan: Angka pada baris dan kolom diikuti huruf sama tidak berbeda pada taraf nyata (a) $5 \%$ menurut uji DMRT. (-) : Tidak terjadi interaksi antar faktor.

\subsection{Pembahasan}

Keadaan awal bibit (stump) menunjukkan bahwa tanaman ke dalam perlakuan panjang sisa potongan akar memiliki tinggi tanaman, bobot segar, dan bobot kering yang tidak berbeda nyata (estimasi pada rendemen 15\%). Selanjutnya pada tanaman yang diberi perlakuan waktu aklimatisasi juga memiliki tinggi tanaman, bobot segar, dan bobot kering yang tidak berbeda nyata (Tabel 1., Tabel 2., dan Tabel 3.) demikian pula pada kombinasi perlakuannya. Setelah panen menunjukkan bahwa panjang sisa potongan akar $5 \mathrm{~cm}$ memberikan hasil pertumbuhan paling baik, meliputi; panjang akar, luas daun, 
bobot segar akar, bobot kering akar, bobot segar tanaman, persentase peningkatan tinggi tanaman, persentase peningkatan bobot kering tanaman. Perlakuan panjang sisa potongan akar $5 \mathrm{~cm}$ juga mengakibatkan pertumbuhan akar baru yang lebih ekstensif ditunjukkan pula dengan menurunnya nisbah (rasio) bobot kering tajuk/akar (Tabel 13.). Hasil ini mendukung laporan sebelumnya yang menyatakan bahwa, pemangkasan akar, mengurangi pertumbuhan tunas, merangsang pertumbuhan akar baru sebagai upaya tanaman untuk mengembalikan rasio tajuk_akar seperti sebelum pemangkasan (Maggs, 1964; Richards dan Rowe, 1977; Randolph dan Wiest, 1981). Laporan lainnya juga menyatakan bahwa, pemangkasan akar menginduksi penurunan rasio tajuk_akar (Tanaka, Walsted dan Borrecco, 1976; Bacon dan Bachelard, 1978; Randolph dan Wiest, 1981), dan berhubungan dengan peningkatan kinerja bibit pohon pasca-transplanting (Benson dan Shepherd, 1977). Menurut Kramer dan Kozlowski (1979), masing-masing spesies memiliki rasio tajuk akar yang khas. Ketika rasio berubah, seperti saat transplanting, tanaman merespon dengan mengalihkan asimilat untuk mengganti bagian yang dipangkas.

Waktu penyapihan bibit kemiri asal cabutan tidak berbeda nyata pada semua parameter pengamatan, tetapi waktu penyapihan 14 minggu menghasilkan tanaman dengan persentase peningkatan bobot kering, dan indeks luas daun tertinggi.

\section{Simpulan}

Tidak terjadi interaksi antara panjang sisa potongan akar dengan waktu penyapihan pada semua parameter pengamatan. Pengaruh utama perlakuan sisa potongan akar $5 \mathrm{~cm}$ menghasilkan persentase peningkatan bobot kering tanaman terbaik $(298,7$ \%). Pengaruh utama perlakuan waktu penyapihan tidak menunjukkan beda nyata pada semua parameter pengamatan.

\section{Pustaka}

Adji, 2000. Rancangan Percobaan Praktis Bidang Pertanian. Kanisius, Yogyakarta

Bacon, G. J. and E. P. Bachelard. 1978. The influence of nursery conditioning treatments on some physiologicalresponses of recently transplanted seedlings of Pinus vcaribaea Mor. var. hondurensisB\& G. Aust. For. Res. 8:171-183.

Bayley A.D. and Kietzka J.W. 1997. Stock quality and field performance of Pinus patula seedlings produced under two nursery growing regimes during seven different nursery production periods. New Forest 13: 341-356.

Benson, A. D. and K. R. Shepherd. 1977. Effects of nursery practice on seedling characteristics and field performance: II. Nursery root wrenching. N. Z. J For. Res. 7(1):68-76.

Brissette J.C. 1991. Development and function of the root systems of southern pine nursery stock. In: Proceedings of the Southern Forest Nursery Association. Mississippi Forestry Commission, Biloxi, MS Jackson, MS, pp 67-81.

Buttrose, M.S. and Mullins, M.G. 1968. Proportional reduction in shoot growth of grapevines with root systems maintained at constant relative volumes by repeated pruning. Australian Journal of Biological Science 21:1095-1101.

Carlson, W. C. 1974. Root initiation induced by root pruning in northern red oak. Forest Res. Rev., Ohio Agr. Res. Develop. Center, Wooster, p. 14-16.

Direktur Jenderal Perkebunan, Departemen Pertanian RI, 2006. Pedoman Budidaya Kemiri.

Febriani, D.N.S., Indradewa, D. dan Waluyo, S. 2010. pengaruh pemotongan akar dan lama aerasi media terhadap pertumbuhan selada (lactuca sativa 1.) nutrient film technique.

Ferree, D.C. 1989. Growth and carbohydrate distribution of young apple trees in response to root pruning and tree density. HortScience 24(1):62-65.

Ferree, D.C. 1992. Time of root pruning influences vegetative growth, fruit size, biennial bearing, and yield of 'Jonathan' apple. Journal of the American Society for Horticultural Science 117(2): 198-202.

Gilman, E. F. and T. H. Yeager. 1988. Root initiation in rootpruned hardwoods. HortScience. 23 (4): 775

Gilman, F.E., 1992. Effect of Root Pruning Prior to Transplanting on Establishment of Southern Magnolia in the Landscape Journal. of Arboriculture 18 (4):

Geisler, D. and Ferree, D.C. 1984. Responses of plants to root pruning. Horticultural Reviews 6: 155-188.

Hamid, 1991. Tanaman kemiri. Edsus Littro Vol. VII No.2. Balittro Bogor :2231

Jacobs D.F., Rose R., Haase D.L. and Alzugaray P.O. 2004. Fertilization at planting inhibits root system development and drought avoidance of Douglas-fir (Pseudotsugamenziesii) seedlings. Ann. For. Sci. 61: 643-652.

Kramer, P. J. and T. T. Kozlowski. 1979. Physiology of Woody Plants. Academic Press, N. Y.

Larson M.M. 1975. Pruning northern red oak seedlings: effects on root regeneration and early growth. Can. J. For. Res. 5: 381-386.

Ma, S.C., Li, F.M., Yang, S.J., Li, C.X., Xu, B.C., and Zhang X.C. 2013. Effects of Root Pruning on Non-Hydraulic Root-Sourced Signal, Drought Tolerance and Water Use Efficiency of Winter Wheat. Science Direct. Journal of Integrative Agriculture. 12(6): 989-998.

Maggs, D. H. 1964. Growth rates in relation to assimilate supply and demand. I. Leaves and roots as limiting regions. J. Expt. Bot. 15:574-583.
McDavid, C.R.; Sagar, G.R., Marshall, C. 1973. The effect of root pruning and 6-Benzylaminopurine on the chlorophyll content, 14C02 fixation and the shoot/root ratio in seedlings of Pisum sativum L. New Phytologist 72:465470.

Miller, F. D., and D. Neely. 1993. The effect of trenching on growth and plant health of selected species of shade trees. J. Arboric. 19 (4): 226-229.

Pramono, A.A., et al., 2010. Pengelolaan Hutan Jati Rakyat Panduan Lapangan untuk Petani. Center for International Forestry Research. ISBN: 978-6028693-19-6

Randolph, W.S. and Wiest, S.C. 1981. Relative importance of tractable factors affecting the establishment of transplanted holly. Journal of the American Society for Horticultural Science 106(2):207-210.

Richards, D. and Rowe, R.N. 1977. Effects of root restriction, root pruning and 6-Benzylaminopurine on the growth of peach seedlings. Annals of Botany 41:729-740.

Rosman, R. dan Djauhariya, E. 2006 Status Teknologi Budidaya Kemiri. Edisi Khusu Balai Penelitian Tanaman Obat dan Aromatik 2: 55-66.

Schupp, J.R. and Ferree, D.C. 1990. Influence of time of root pruning on growth, mineral nutrition, net photosynthesis and transpiration of young apple trees. Scientia Horticulturae 42:299-306

Tanaka, Y., J.D. Walsted and J.E. Borrecco. 1976. The effect of wrenching on morphology and field performance of Douglas fir and loblolly pine seedlings. Can. J. Forest. Res.6:453-458.

Wilcox, H. 1955. Regeneration of injured root systems of noble fir. Bot. Gaz. 116: $221-234$.

Williams H.M., South D.B. and Webb A. 1988. Effects of fall irrigation on morphology and root growth potential of loblolly pine seedlings growing in sand. South Afr. For. J. 147: 1-5.

Yildiz, K., F., Koyuncu dan H., Yilmaz., 2005. Effect of root pruning on xylem exudation of seedling and graft success of walnut (Juglans regia L.) Anadolu, J. of AARI 15 (1), $44-48$. 